\title{
Immunohistochemical Expression of Cancer Stem Cell marker Aldehyde dehydrogenase 1B1 (ALDH1B1) in Colorectal
}

\section{Carcinoma}

\author{
Eman MS Muhammad ${ }^{1}$, Omar AS Farghali ${ }^{2}$ \\ Zeinab HA El Badawy ${ }^{3}$, Sheren FM Ahmed ${ }^{4}$ \\ Amira AA Ahmed ${ }^{5}$ \\ Departments of Pathology ${ }^{1,3,4,5}$ and surgery ${ }^{2}$, Sohag University
}

\section{Abstract}

Background: Colorectal cancer (CRC) is the third most common cause of cancer-related death in the US. One out of four patients presenting with conventionally staged node negative disease (AJCC Stage I and II), and over 50\% of patients with Stage III disease will develop local recurrence and/ or metastases. Across all stages, approximately $30 \%$ of patients will develop distant metastases. Once metastases become clinically evident prognosis is often fatal. Biomarkers capable of predicting progression, risk stratification and therapeutic benefit are needed. CRCSC markers will identify a group of patients at high risk for progression. ALDH1 has been reported as a cancer stem cell marker in pancreatic, breast, prostate, and lung cancer, multiple myeloma and leukemia. By IHC analysis, human ALDH1B1 was found to be expressed at high levels in the small intestine, liver, and pancreas, and at lower levels in the lung and colon. This study aims to investigate ALDH1B1 expression in different types of colorectal carcinoma and correlate this expression with different clinicopathological parameters.

Materials and Methods: ALDH1B1 immunostaining was studied in 50 specimens of colorectal carcinoma using avidin-biotin peroxidase method. Results: ALDH1B1 was strongly expressed in 12/50 (58\%) of cases of colorectal carcinoma, moderately expressed in 31/50 (36\%) of cases and weekly expressed in 7/50 (6\%) of cases. ALDH1B1 expression in colorectal carcinoma was significantly positively correlated with tumor size $(\mathrm{p}=0.021)$, tumor grade $(\mathrm{p}=$ $0.035)$ where the highest expression levels were associated with moderately or poorly differentiated tumors and positive regional lymph node status $(p=0.038)$.

Conclusion: The up-regulation of ALDH1B1 with increasing grade of colorectal carcinoma and presence of LN metastases indicates that ALDH1B1 might play a role in carcinogenesis and tumor progression.

Keywords: Colorectal cancer, stem cell marker.

Abbreviation: Aldehyde dehydrogenase 1B1 (ALDH1B1), Colorectal cancer stem cell (CRCSC) markers, Immunohistochemistry (IHC).

\section{Introduction}

Colorectal cancer (CRC) is the third most common cause of cancer-related death in the US. Across all stages, approximately $30 \%$ of patients will develop distant metastases (Siegel et al., 2011).

Biomarkers capable of predicting progression, risk stratification and therapeutic benefit are needed. Cancer stem cells are thought to be responsible for tumor initiation, dissemination and treatment failure. Therefore, $\mathrm{CRC}$ stem cell (CRCSC) markers will identify a group of patients at high risk for progression (Manfredi et al., 2006).

ALDH1A1 and ALDH1B1 belong to the family 1 of ALDH superfamily (Stagos et al., 2010). The ALDH superfamily of enzymes catalyze the NAD (P)+dependent oxidation of wide varieties of endogenous and exogenous aldehyde 
substrates to their corresponding acids (Vasiliou et al., 2004).

High ALDH1 activity is detected in stem and progenitor cells of various lineages. Enhanced ALDH1 expression was found in areas where epithelial progenitor cells localize within normal breast, colon, liver, pancreas and stomach (Deng et al., 2010).

In the colon, the expression of ALDH1B1 appeared to be confined to a small number of undifferentiated cells that are consistent with being the stem cell compartment. However, it is expressed at higher levels than ALDH1A1 in colonic adenocarcinomas (Chen et al., 2011)

Patients and methods

Tissue samples

Fifty specimens of colectomy for colorectal carcinoma, sent to Pathology Laboratory of Sohag University Hospital from Department of Surgery through the period from January 2015 to December 2017, were included in the present study. The colorectal carcinoma was graded in accordance with the WHO grading criteria according to (Hamilton et al., 2010).

Pathological stage of the tumor (depth of invasion) and lymph node status were also evaluated according to AJCC

(Weisenberg E, 2018)

\section{Immunohistochemistry}

After evaluating (H\&E) stained slides. Serial sections from each block were used for immunohistochemistry. A dilution of 1:500 from Rabbit polyclonal antibody against human ALDH1B1 (Catalog \# GTX107279, GENE TEX INTERNATIONAL, Corporation, Fremont, USA) was used. Sections from squamous cell carcinoma of skin were used as a positive control for ALDH1B1. Scoring of immunoreactions and statistical analyses

ALDH1B1 protein expression appeared as brownish cytoplasmic staining. The immunoreactive score (IRS) was determined by multiplying an estimate of the percentage of the immunoreactive cells (quantity score; QS) with an estimate of the staining intensity (intensity score; IS) according to Zlobec et al., (2009). Staining quantity is scored as follows: No staining $=0,1-10 \%$ of cells stained $=1,11-50 \%$ of cells stained $=2,51-80 \%$ of cells stained $=3,81$ $100 \%$ of cells stained $=4$. Staining intensity is scored on a scale of 0-3 where: No staining $=0$, Weak $=1$, Moderate $=2$, Strong $=3$. An IRS of 0-4 was considered weak, 6-8 was moderate, and 9-12 was considered strong.

\section{Results}

The age range of the patients included in this study was 29 - 80 years, with a mean \pm $\mathrm{SD}$ and a median of $56.2 \pm 13.5$ and 57.5 years respectively. Males were 27/50 (54\%) and females were 23/50 (46\%). Regarding tumor size, 21/50 (16\%) cases were $\leq 5 \mathrm{~cm}$ and $29 / 50(84 \%)$ cases were $>5 \mathrm{~cm} .31 / 50(62 \%)$ cases were left sided tumors whereas 19/50 (38\%) cases were right sided.

The representative H\&E stained sections of the collected 50 specimens of colorectal carcinoma were evaluated according to the WHO classification (Hamilton et al., 2010), into the following histological types:

- Thirty four 34/50 (68\%) cases were conventional adenocarcinoma

- Twelve $12 / 50(24 \%)$ cases were mucinous adenocarcinoma

- Four 4/50 (8\%) cases were signet ring carcinoma 
LVI were evaluated histopathologically. TNM pathological classification and lymph node status were carried out according to the AJCC (Weisenberg 2018).

Colorectal carcinoma was graded in accordance with the WHO grading criteria (Hamilton et al., 2010) based on the percentage of glandular differentiation in the tumor into:

- Nineteen cases $(19 / 50 ; 38 \%)$ were grade I; well differentiated tumor > 95\% gland forming.

- Twenty five cases $(25 / 50 ; 50 \%)$ were grade II; moderately differentiated tumor 50$95 \%$ gland forming.

- Six cases $(6 / 50 ; 12 \%)$ were grade III; poorly differentiated tumor < 50\% gland forming.

- Signet ring cell carcinoma were considered to be grade III

ALDH1B1 protein expression appeared as brownish granular cytoplasmic staining. It showed variation in its expression among different types and grades of colorectal carcinoma.

ALDH1B1 was strongly expressed in 12/50 (58\%) of cases of colorectal carcinoma from them 8/12 (66.67\%) cases were conventional adenocarcinoma. ALDH1B1 was moderately expressed in $31 / 50(36 \%)$ of cases and weekly expressed in $7 / 50(6 \%)$ of cases.

Among the cases strongly expressing ALDH1B1 6/12 was grade II and 4/12 was grade III tumor.

Among the studied parameters; ALDH1B1 showed significant correlation with tumor size $(\mathrm{p}=0.021)$, tumor grade $(\mathrm{p}=0.035)$, and lymph node status $(\mathrm{p}=0.038)$ as shown in. However, statistical evaluation of ALDH1B1 expression according to age, sex, tumor location, histologic type, depth of tumor invasion and LVI showed no significance. 
Table 1: Correlation between ALDH1B1 expression and the studied Clinico-pathological Parameters

\begin{tabular}{|c|c|c|c|c|c|}
\hline \multirow[t]{2}{*}{$\begin{array}{l}\text { Clinico-pathological } \\
\text { Parameter }\end{array}$} & \multirow{2}{*}{$\begin{array}{l}\text { NO of } \\
\text { cases } \\
(50 \\
\text { cases })\end{array}$} & \multicolumn{3}{|c|}{ ALDH1B1 expression } & \multirow[t]{2}{*}{ P value } \\
\hline & & $\begin{array}{l}\text { Weak } \\
\text { IRS } \\
\text { ( } 7 \text { cases) }\end{array}$ & $\begin{array}{l}\text { Moderate } \\
\text { IRS } \\
\text { (31 cases) }\end{array}$ & $\begin{array}{l}\text { Strong } \\
\text { IRS } \\
\text { (12 cases) }\end{array}$ & \\
\hline $\begin{array}{l}\text { Age } \\
\leq \mathbf{5 0} \text { years } \\
>\mathbf{5 0} \text { years }\end{array}$ & $\begin{array}{l}17 \\
33\end{array}$ & $\begin{array}{l}3(17.65 \%) \\
4\end{array}$ & $\begin{array}{l}11(64.70 \%) \\
10\end{array}$ & $\begin{array}{l}\mathbf{5}(29.41 \%) \\
7\end{array}$ & 0.895 (NS) \\
\hline $\begin{array}{l}\text { Sex } \\
\text { Males } \\
\text { Females }\end{array}$ & $\begin{array}{l}27 \\
23\end{array}$ & $\begin{array}{l}3(11.11 \%) \\
4(17.39 \%)\end{array}$ & $\begin{array}{l}15(55.55 \%) \\
16(69.56 \%)\end{array}$ & $\begin{array}{l}\text { 9(33.33\%) } \\
3(13.04 \%)\end{array}$ & $0.238(\mathrm{NS})$ \\
\hline $\begin{array}{l}\text { Tumor size } \\
\leq 5 \mathrm{~cm} \\
>5 \mathrm{~cm}\end{array}$ & $\begin{array}{l}21 \\
29\end{array}$ & $\begin{array}{l}3(14.58 \%) \\
4(13.79 \%)\end{array}$ & $\begin{array}{l}17(80.95 \%) \\
14(48.27 \%)\end{array}$ & $\begin{array}{c}1(04.76 \%) \\
11(37.93 \%)\end{array}$ & $0.021 *$ \\
\hline $\begin{array}{l}\text { Tumor location } \\
\text { Right } \\
\text { Left }\end{array}$ & $\begin{array}{l}19 \\
31\end{array}$ & $\begin{array}{l}3(15.79 \%) \\
4(12.90 \%)\end{array}$ & $\begin{array}{l}11(57.89 \%) \\
20(64.52 \%)\end{array}$ & $\begin{array}{l}5(26.31 \%) \\
7(22.58 \%)\end{array}$ & $0.895(\mathrm{NS})$ \\
\hline $\begin{array}{l}\text { Tumor grade } \\
\text { I } \\
\text { II } \\
\text { III }\end{array}$ & $\begin{array}{l}19 \\
25 \\
6\end{array}$ & $\begin{array}{l}7(36.84 \%) \\
0 \\
0\end{array}$ & $\begin{array}{l}10(52.63 \%) \\
19(76.00 \%) \\
2(33.33 \%)\end{array}$ & $\begin{array}{l}2(10.53 \%) \\
6(24.00 \%) \\
4(66.67 \%)\end{array}$ & 0.001* \\
\hline $\begin{array}{l}\text { Histologic type } \\
\text { Conventional adenocarcinoma } \\
\text { Mucinous carcinoma } \\
\text { Signet ring carcinoma }\end{array}$ & $\begin{array}{l}34 \\
12 \\
4\end{array}$ & $\begin{array}{l}6(17.65 \%) \\
0 \\
1(25.00 \%)\end{array}$ & $\begin{array}{l}20(58.82 \%) \\
8(66.67 \%) \\
3(75.00 \%)\end{array}$ & $\begin{array}{l}8(23.54 \%) \\
4(33.33 \%) \\
0\end{array}$ & $0.412(\mathrm{NS})$ \\
\hline $\begin{array}{l}\text { Depth of tumor invasion }(\mathrm{T}) \\
\text { T1 } \\
\text { T2 } \\
\text { T3 }\end{array}$ & $\begin{array}{l}6 \\
19 \\
25\end{array}$ & $\begin{array}{l}0 \\
4(21.05 \%) \\
3(12.00 \%)\end{array}$ & $\begin{array}{r}3(50.00 \%) \\
11(57.89 \%) \\
17(68.00 \%)\end{array}$ & $\begin{array}{l}3(50.00 \%) \\
4(21.05 \%) \\
5(20.00 \%)\end{array}$ & $0.427(\mathrm{NS})$ \\
\hline $\begin{array}{l}\text { Surgical resection margin } \\
\text { Free } \\
\text { Positive }\end{array}$ & $\begin{array}{l}42 \\
8\end{array}$ & $\begin{array}{l}7(16.67 \%) \\
0\end{array}$ & $\begin{array}{r}27(64.28 \%) \\
4(50.00 \%)\end{array}$ & $\begin{array}{l}8(19.05 \%) \\
4(50.00 \%)\end{array}$ & $0.120(\mathrm{NS})$ \\
\hline $\begin{array}{l}\text { Lymph node status } \\
\text { N0 } \\
\text { N1 } \\
\text { N2 }\end{array}$ & $\begin{array}{l}23 \\
14 \\
13\end{array}$ & $\begin{array}{l}4(17.39 \%) \\
1(07.14 \%) \\
2(15.38 \%)\end{array}$ & $\begin{array}{l}13(56.52 \%) \\
13(92.86 \%) \\
5(38.46 \%)\end{array}$ & $\begin{array}{l}6(26.09 \%) \\
0 \\
6(46.15 \%)\end{array}$ & 0.038* \\
\hline $\begin{array}{l}\text { LVI } \\
\text { Present } \\
\text { Absent }\end{array}$ & $\begin{array}{l}8 \\
42\end{array}$ & $\begin{array}{l}1(12.50 \%) \\
6(14.28 \%)\end{array}$ & $\begin{array}{r}5(62.50 \%) \\
26(61.90 \%)\end{array}$ & $\begin{array}{c}2(25 \%) \\
10(23.81 \%)\end{array}$ & $0.990(\mathrm{NS})$ \\
\hline
\end{tabular}

$\mathrm{P}$ - Value was calculated by Chi-square test, ${ }^{*}=$ Significant, NS= Non-Significant

Table 2: Correlation between ALDH1B1 expression and age of the studied patients

\begin{tabular}{|l|l|l|}
\hline \multirow{2}{*}{ Parameter } & Age \\
\cline { 2 - 3 } & r & P-value \\
\hline ALDH1B1 & 0.096 & 0.507 \\
\hline
\end{tabular}

$\mathrm{r}=$ Spearman's correlation coefficient

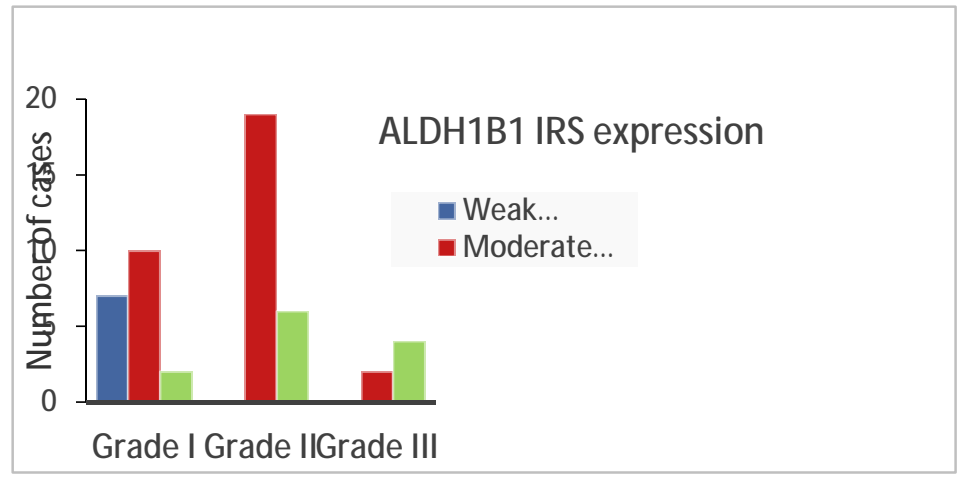

Graph (1): Correlation between ALDH1B1 expression and the grade of tumor 


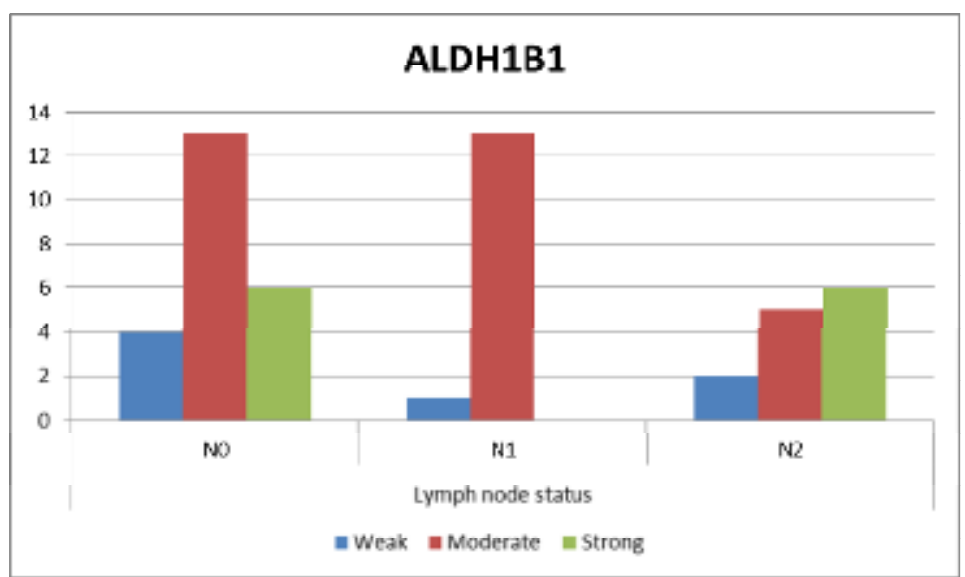

Graph (2): Correlation between EPCAM expression and lymph node status

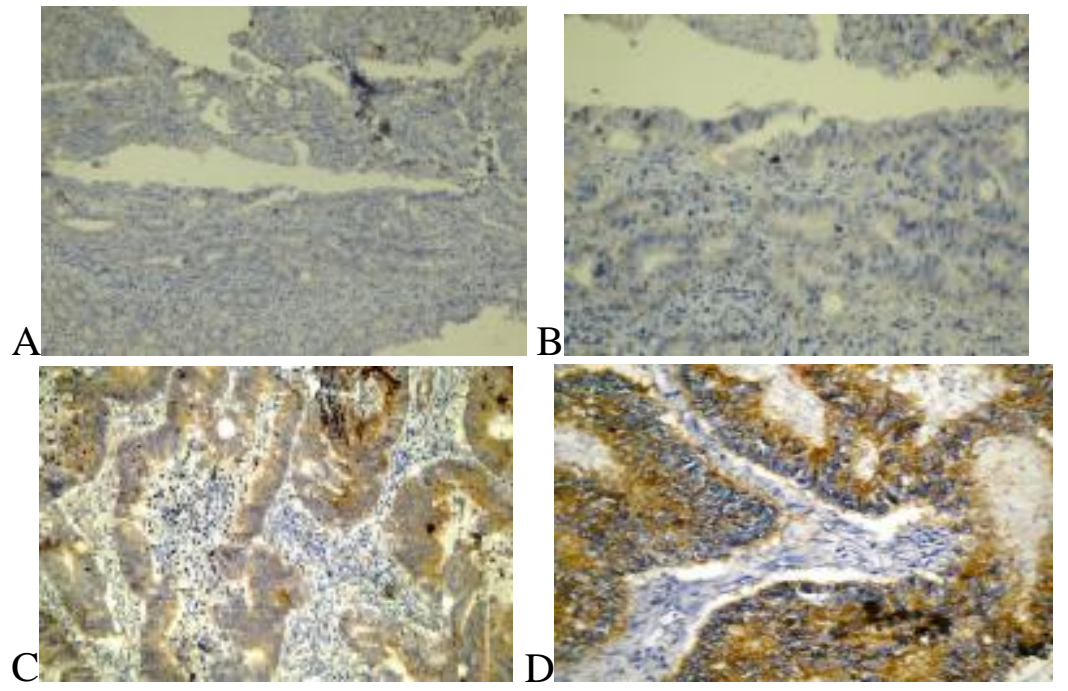

Figure (29): A) Adenocarcinoma grade I with very weak ALDH1B1 expression (X200). B) Adenocarcinoma grade I with very weak ALDH1B1 expression (X400). C) Moderate ALDH1B1 expression in adenocarcinoma grade II (X200). D) Adenocarcinoma grade III with strong ALDH1B1 expression (X400).

\section{Discussion}

Our study included 50 specimens of colorectal carcinoma removed by colectomy. These tumors were investigated for the expression of ALDH1B1 glycoprotein. The IRS of ALDH1B1 was defined in tumor tissue and was correlated with some clinicopathological variables (age, sex, tumor size, tumor location, tumor grade, depth of tumor invasion, surgical resection margin, LVI and lymph node status).

The age range of the studied patients was 29-80 years, with the highest age incidence was between 50-59 years, with mean \pm SD was $56.2 \pm 13.5$ years, the median age was 57.5 years. The male to female ratio was 1.3: 1 .

\section{Immunohistochemical findings:}

Current study showed that ALDH1B1 was expressed in all cases (100\%) of colorectal carcinoma. It was strongly expressed in 12/50 (24\%), moderately expressed in $31 / 50(62 \%)$, and weakly expressed in $7 / 50(14 \%)$ case. These findings are similar to those reported by Langan et al., (2012) and Langan et al., (2013) who found that all cases $(100 \%)$ of CRC were positive for ALDH1B1. While Chen et al., (2011) found that $97.5 \%$ of cases of CRC showed 
ALDH1B1 positivity. In contrast Lugli et al., (2010) found that only 79\% of CRC cases showed ALDH1B1 positivity, this difference may be due to difference in methodology and certainly the choice of cutoff scores for the definition of positive staining or staining intensity.

Our study showed that ALDH1B1 expression in colorectal carcinoma was significantly positively correlated with tumor grade $(p=0.001)$ where the highest expression levels were associated with moderately or poorly differentiated tumors. Similar results were found by Lugli et al., (2010), Chen et al., (2011), Langan et al., (2012) and Langan et al., (2013). ALDH1B1expression was significantly correlated with lymph node status $(\mathrm{p}=$ 0.038) where expression of ALDH1B1 increases with increasing node stage (from N0 to N2) in accordance with Chen et al., (2011) , Langan et al., (2012) and Fitzgerald et al., (2014).

This study showed significant association between ALDH1B1 expression and tumor size $(p=0.021)$ where it increases in tumors more than 5 $\mathrm{cm}$ in greatest dimension. To the best of our knowledge, no previous studies discuss this correlation.

Furthermore, we found that ALDH1B1 expression in cases of colorectal carcinoma was not correlated with patients' age, sex, depth of tumor invasion, pathological type, LVI or surgical resection margin. Our results went in agreements with the results of Lugli et al., (2010), Chen et al., (2011), Langan et al., (2012), Langan et al., (2013) and Fitzgerald TL et al., (2014).

\section{Conclusion}

- The up-regulation of ALDH1B1 with increasing grade of colorectal carcinoma and/or presence of $\mathrm{LN}$ metastases indicates that ALDH1B1 might play a role in carcinogenesis and tumor progression.

- Our results suggest that overexpression of ALDH1B1 may represent unfavorable prognostic factor in CRC.

- These findings may lend themselves to a new strategy of individualized adjuvant therapy selection and posttreatment surveillance aimed at identifying patients with the highest likelihood of disease recurrence or progression.

\section{Recommendations}

1. Studying the expression of ALDH1B1 on a large number of cases and different varieties of CRC.

2. Prospective studies properly powered based on this study should be undertaken to determine the significance of these early findings; follow up of patients and getting enough information about distant metastasis to emphasize the correlation between ALDH1B1 expression and the patient survival and disease outcome.

\section{References:}

1. Deng S, Yang X, Lassus H, Liang S, Kaur S, Ye Q, Li C, Wang LP, Roby KF, Orsulic S, Connolly DC, Zhang Y, Montone K, Bützow R, Coukos G, Zhang L. Distinct expression levels and patterns of stem cell marker, aldehyde dehydrogenase isoform 1 (ALDH1), in human epithelial cancers. PLoS One 2010; 5:10277.

2. Fitzgerald TL, Rangan S, Dobbs L, Starr S, Sigounas G, J Surg Res. The impact of Aldehyde dehydrogenase 1 expression on prognosis for metastatic colon cancer. 2014; 192:82-89.

3. Hamilton SR, Bosman FT, Boffetta P, Carneiro F, Hruban RH, Theise ND. Carcinoma of the colon and rectum. In: 
WHO Classification of Tumours of the Digestive System. Lyon: IARC Press 2010:134-146.

4. Langan RC, Mullinax JE, Raiji MT, Upham T, Summers T, Stojadinovic A, Avital I. Colorectal cancer biomarkers and the potential role of cancer stem cells. J Cancer. 2013; 4:241-250.

Langan RC, Mullinax JE, Ray S, Raiji MT, Schaub N, Xin HW, Koizumi T, Steinberg SM, Anderson A, Wiegand G, Butcher D, Anver M, Bilchik AJ, Stojadinovic A, Rudloff U, Avital I. A Pilot Study Assessing the Potential Role of non-CD133 Colorectal Cancer Stem Cells as Biomarkers. J Cancer. 2012; 3: 231-240.

5. Lugli A, Iezzi G, Hostettler I, Muraro MG, Mele V, Tornillo L, Carafa V, Spagnoli G, Terracciano L, Zlobec I. Prognostic impact of the expression of putative cancer stem cell markers CD133, CD166, CD44s, EPCAM, and ALDH1 in colorectal cancer. Br J Cancer 2010; 103:382-390.

6. Manfredi S, Bouvier AM, Lepage C, Hatem C, Dancourt V, Faivre J. Incidence and patterns of recurrence after resection for cure of colonic cancer in a well defined population. Br J Surg 2006; 93:1115-1122.
7. Siegel R, Ward E, Brawley O, Jemal A. Cancer statistics: the impact of eliminating socioeconomic and racial disparities on premature cancer deaths. CA Cancer J Clin. 2011; 61:212-236.

8. Stagos D, Chen Y, Brocker C, Donald E, Jackson BC, Orlicky DJ, Thompson DC, Vasiliou V. Aldehyde dehydrogenase 1B1: molecular cloning and characterization of a novel mitochondrial acetaldehyde-metabolizing enzyme. Drug Metab Dispos. 2010; 38:1679-1687.

9. Vasiliou V, Pappa A, Estey T. Role of human aldehyde dehydrogenases in endobiotic and xenobiotic metabolism. Drug Metab Rev. 2004; 36:279-299.

10.Weisenberg E. TNM staging of colorectal carcinoma (AJCC 8th edition). PathologyOutlines.com. 2018; 25:14541458 .

11.Zlobec I, Gunthert U, Tornillo L, Iezzi G, Baumhoer D, Terracciano L, LuglI A. Systematic assessment of the prognostic impact of membranous CD44v6 protein expression in colorectal cancer. Histopathology. 2009; 55:564575 . 
